\title{
The time has come to test the beta cell preserving effects of exercise in patients with new onset type 1 diabetes
}

\author{
Parth Narendran • Thomas P. Solomon • Amy Kennedy • \\ Myriam Chimen • Rob C. Andrews
}

Received: 1 August 2014 / Accepted: 22 September 2014 / Published online: 4 November 2014

(C) Springer-Verlag Berlin Heidelberg 2014

\begin{abstract}
Type 1 diabetes is characterised by immunemediated destruction of insulin-producing beta cells. Significant beta cell function is usually present at the time of diagnosis with type 1 diabetes, and preservation of this function has important clinical benefits. The last 30 years have seen a number of largely unsuccessful trials for beta cell preservation, some of which have been of therapies that have potential for significant harm. There is a need to explore new, more tolerable approaches to preserving beta cell function that can be implemented on a large clinical scale. Here we review the evidence for physical exercise as a therapy for the preservation of beta cell function in patients with newly diagnosed type 1 diabetes. We highlight possible mechanisms by which
\end{abstract}

Parth Narendran and Thomas P. Solomon contributed equally to this article.

P. Narendran $\cdot$ A. Kennedy $\cdot$ M. Chimen

The Institute of Biomedical Research, School of Clinical and Experimental Medicine, College of Medical and Dental Sciences,

University of Birmingham, Edgbaston, Birmingham B15 2TT, UK

P. Narendran · A. Kennedy

Department of Diabetes, University Hospitals Birmingham NHS

Foundation Trust, Birmingham, UK

\section{T. P. Solomon}

Department of Biomedical Sciences, University of Copenhagen, Copenhagen, Denmark

R. C. Andrews

School of Clinical Science, University of Bristol, Bristol, UK

R. C. Andrews

Department of Diabetes \& Endocrinology, Taunton \& Somerset NHS

Foundation Trust, Taunton, UK

P. Narendran $(\bowtie)$

The Institute of Biomedical Research, The Medical School, University of Birmingham, Edgbaston, Birmingham B15 2TT, UK e-mail: p.narendran@bham.ac.uk exercise could preserve beta cell function and then present evidence from other models of diabetes that demonstrate that exercise preserves beta cell function. We conclude by proposing that there is now a need for studies to explore whether exercise can preserve beta cell in patients newly diagnosed with type 1 diabetes.

Keywords Betacell $\cdot$ Exercise $\cdot$ Immune intervention · Type 1 diabetes

$\begin{array}{ll}\text { Abbreviations } \\ \text { GH } & \text { Growth hormone } \\ \text { GLP-1 } & \text { Glucagon-like peptide-1 } \\ \text { GSIS } & \text { Glucose-stimulated insulin secretion } \\ \text { IL-1ra } & \text { IL-1 receptor agonist } \\ \text { Px } & \text { Pancreatectomised } \\ \text { STRRIDE } & \text { Studies of a Targeted Risk Reduction } \\ & \text { Intervention through Defined Exercise } \\ \text { STZ } & \text { Streptozotocin } \\ \text { TLR } & \text { Toll-like receptor } \\ \text { ZDF } & \text { Zucker diabetic fatty }\end{array}$

Introduction

Type 1 diabetes is a chronic inflammatory autoimmune disease characterised by destruction of insulin-producing beta cells and subsequent insulin deficiency [1]. The loss of beta cells that results in type 1 diabetes is gradual, such that half the beta cell function can be viable at the time a patient presents clinically with the symptoms of type 1 diabetes [2]. Whilst it is generally assumed that residual beta cells are completely destroyed after diagnosis, studies now indicate that these cells persist over the long term [3]. 
The preservation of residual beta cell function has important clinical benefits. A meal-stimulated C-peptide value of $>200 \mathrm{pmol} / \mathrm{l}$ is associated with improved glucose control for the first 4 years after diagnosis, reduced risk of developing retinopathy and nephropathy, and a $>50 \%$ reduction in the rates of hypoglycaemia [4]. These benefits are clinically significant. Interventions that have the potential to preserve beta cell function are well worth striving for because they should lead to better early control and reduced incidence of complications.

With this in mind, a number of studies over the past 30 years have attempted to preserve beta cell function in patients with type 1 diabetes [5]. Many of these trialled agents act through 'suppressing' the inflammatory autoimmune process that targets the beta cell. Side effects of immune suppression can include cancer and re-activation of previous infection $[6,7]$. Furthermore, these therapies have yet to demonstrate long-term and meaningful clinical benefit. The reasons for the failure of these therapies have been reviewed elsewhere [8] and are not the subject of this article. Whilst there is a clear need to continue investigating such novel therapies, there is also a pressing need to examine new therapies with an acceptable side-effect profile that could potentially be used as an adjunct to the novel medicinal products under investigation.

In this 'For debate' article, we put forward a case for physical exercise being such a therapy, and one that should now be tested in clinical trials.

\section{Search strategy}

We searched the Cochrane Library (2009-2014) and MEDLINE (2009-2014). We used the search terms 'beta cell', and 'exercise'. In Medline, 'beta cell' encompassed diabetes mellitus, type 2 / or glucose/ or diabetes mellitus, type 1 / or pancreas/ or insulin/ or rats/ or insulin-secreting cells/ or diabetes mellitus/ or islets of Langerhans/ or Mice/ resulting in 459747 results. In Medline. 'exercise' [metabolism, physiology] resulted in 8199 results. Together, these searches resulted in 706 articles since 2009. These articles were reviewed by P. Narendran, and initial selection for inclusion based on title and abstract. We did not exclude commonly referenced and relevant older publications from outside this time period. We also searched the reference lists of articles identified by this search strategy and selected those we judged relevant. Review articles and book chapters are cited to provide readers with more details and more references than this review has room for.

\section{What are the mechanisms through which exercise might preserve beta cell mass?}

Beta cell mass could potentially be preserved through two broad mechanisms: beta cell proliferation and reduced beta cell death. Evidence from in vitro and rodent studies suggests that exercise has the potential to affect both of these mechanisms (Fig. 1).

Exercise and beta cell proliferation Physical exercise elicits marked elevations in circulating levels of growth hormone (GH), IGF-1, glucagon-like peptide 1 (GLP-1), IL-6 and IL-1 receptor agonist (IL-1ra), all of which are thought to have a positive effect on beta cell mass. For example, GH increases beta cell proliferation in vitro [9] and protects beta cell lines against IL- $1 \beta$-, IFN- $\gamma$ - and TNF- $\alpha$-induced apoptotic cell death [10]. Increased IGF-1 signalling is thought to play a role in the increase in beta cell mass seen with exercise in $90 \%$ pancreatectomised (Px) rats [11, 12]. IL-6, which is increased during exercise and elicits the increased circulating levels of GLP-1 during exercise, has an indirect effects on beta cell proliferation via GLP-1 [13]. In addition, in 90\% Px rats, exendin-4 (a GLP-1 receptor agonist) increases beta cell mass by enhancing islet IRS-1 expression via activation of cAMP response element-binding protein (CREB), and increased expression of pancreatic and duodenal homeobox 1 (PDX-1), the transcription factor involved in beta cell proliferation [11]. Finally, IL-1ra, which is increased in the circulation following exercise [14], likely as a secondary consequence of increased IL-6 [15], antagonises the effects of IL-1 $\beta$, which is one of the central initiators of proinflammatory mechanisms because it initiates apoptotic beta cell death in both type 1 and type 2 diabetes. Accordingly, randomised controlled trials using either recombinant human IL-1 ra drugs (anakinra) or specific IL-1 $\beta$ antibody drugs (gevokizumab) have shown promise for the treatment of both type 1 and type 2 diabetes $[16,17]$.

Exercise and reduction in beta cell death A number of mechanisms have been proposed. First, exercise reduces visceral fat mass, a source of fat derived cytokines (adipokines). Adipokines such as leptin and TNF- $\alpha$ have a proinflammatory effect, and others such as adiponectin have an antiinflammatory effect [18]. Exercise decreases circulating concentrations of leptin and TNF- $\alpha$, and increases circulating adiponectin [19]. Switching the cytokine environment to an anti-inflammatory profile could potentially modulate the immune response that leads to beta cell destruction in type 1 diabetes. Work in our laboratory has also demonstrated that the expression of adiponectin receptors by peripheral blood immune cells is reduced in patients with type 1 diabetes [20]. This reduction in receptor expression releases effector $\mathrm{T}$ cells from the anti-inflammatory effects of adiponectin, resulting in a proinflammatory response to beta cell antigen. We have further demonstrated that exercise increases the expression of adiponectin receptors, providing a potential mechanism whereby exercise can directly reduce $\mathrm{T}$ cell responses to the pancreatic islet in an antigen-specific manner. 


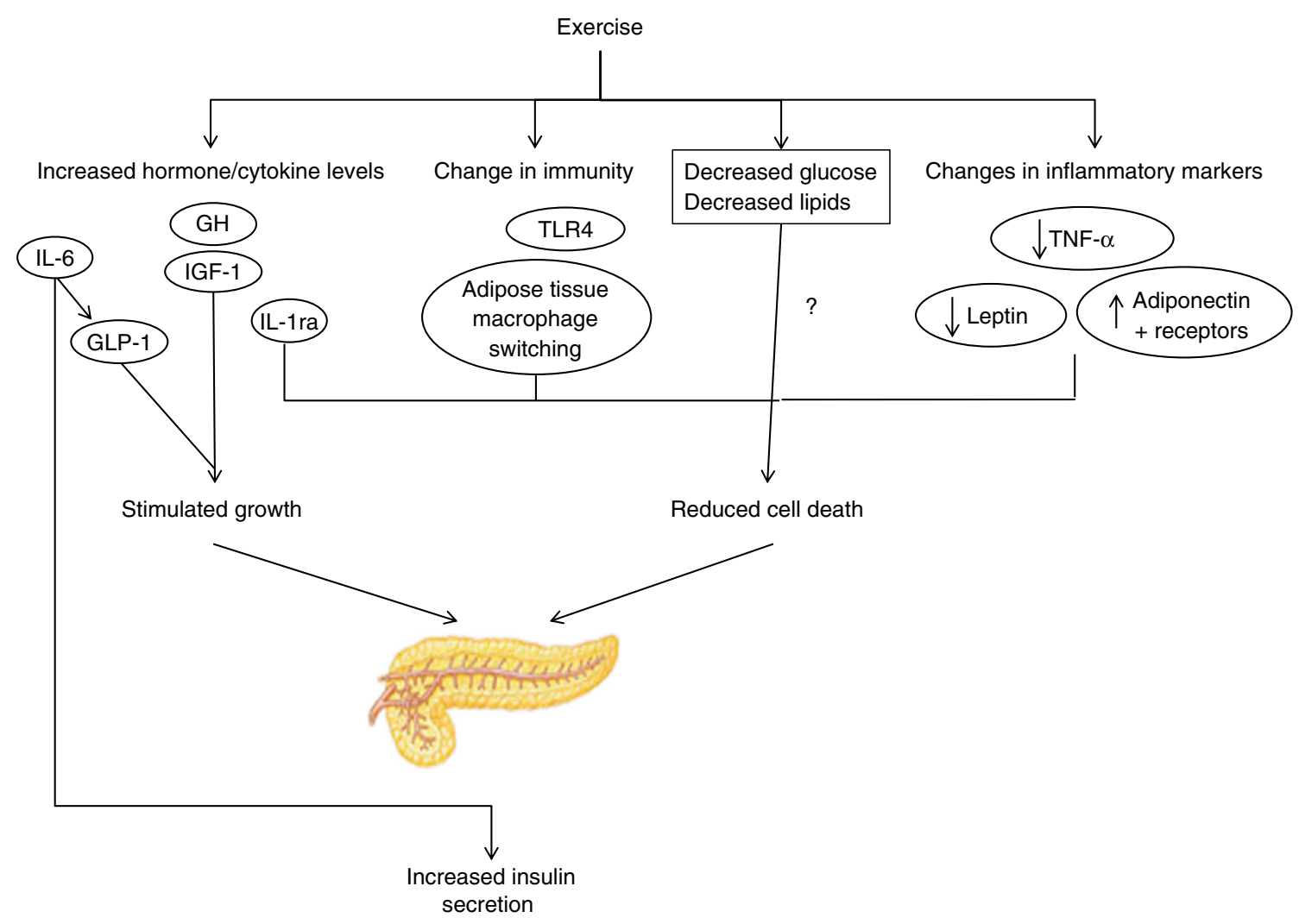

Fig. 1 Potential mechanisms through which exercise could improve beta cell mass and/or function. Several metabolites and endocrine signals are increased in the circulation during or following exercise. We have identified a short list of these compounds that have documented beneficial

Second, exercise modulates innate immunity by reducing the expression of Toll-like receptors (TLR, particularly TLR4) on monocyte/macrophage immune cells [21]. This results in a reduction in expression of MHC class II and co-stimulatory molecules required for antigen presentation [22], and provides a mechanism whereby destructive immune responses to the beta cell can be modulated.

Finally, exercise helps to normalise plasma glucose [23] and serum lipids [24] in individuals with, or at risk of, diabetes. These factors when chronically elevated are known to cause beta cell death. This is important because chronic exposure of human islets to hyperglycaemia induces inflammation (increased IL-1 $\beta$ expression), impairs glucose-stimulated insulin secretion, and augments beta cell apoptosis [25]. Normalising plasma glucose in diabetic patients using intensive insulin treatment increases both glucose-stimulated insulin secretion (GSIS) [26] and GLP-1-induced potentiation of GSIS [27]. Similarly, prolonged lipid infusion has been associated with a reduction in insulin secretion in both animal models and healthy humans $[28,29]$. Chronic exposure of beta cells to NEFA impairs insulin secretion and induces beta cell apoptosis [30]. Clinically, trials of lipid-lowering therapy for the preservation of beta cell function have shown some benefit in patients with markers of residual systemic inflammation [31]. effects on beta cell mass and/or function. We have included the speculated beneficial effects of exercise on reducing glucolipotoxicity on beta cell mass and/or function

\section{What is the evidence for physical exercise preserving beta cell mass and function in non-humans?}

Rodent models of type 1 diabetes can be generated in a number of ways. One is to ablate beta cells using a beta cell toxic agent such as streptozotocin (STZ). When initiated 4 weeks prior to STZ treatment in rats, exercise training preserved beta cell number and increased beta cell insulin content [32]. Furthermore in a study by Huang et al, while exercise did not improve islet diameter or beta cell mass, islet insulin content and insulin secretion was greater in exercised vs sedentary STZ-induced diabetic mice [33]. Px models of type 1 diabetes have also been examined. Shima et al showed that although exercise training failed to improve beta cell proliferation in $70 \%$ Px rats, the mass of insulin per beta cell increased [34]. Choi and colleagues reported that training enhanced beta cell proliferation and mass in $90 \%$ Px rats [11]. This finding was supported by Park et al, who demonstrated that training prevented the decline in first-phase insulin secretion in perfused islets and increased beta cell mass (via increased proliferation and reduced apoptosis) from high-fatfed $90 \%$ Px rats [12]. The increase in insulin-positive cells measured by immunohistochemistry reported across these studies varied from 20 to $50 \%$. 
The Zucker diabetic fatty (ZDF) rat model of type 2 diabetes has also provided evidence for a beneficial effect of training on beta cell mass. Pold et al showed that chronic 5' AMPactivated protein kinase (AMPK) activation through exercise in 5-week-old ZDF rats led to near normalised beta cell morphology with increased beta cell mass and normal staining for insulin [35]. The same effects of exercise were demonstrated by Király et al [36], who conducted a study showing that exercise training in 6-week-old ZDF rats led to an increase in insulin secretory function as well as increased beta cell proliferation [37]. In addition to these effects on beta cell mass, a more recent study has demonstrated that voluntary running prevents diabetes in ZDF rats by sustaining beta cell compensation for insulin resistance with preserved islet insulin mRNA and protein levels [38]. Further evidence comes from the finding that treadmill exercise from weeks 5 to 9 of age in growth-retarded litter offspring led to a $\sim 60 \%$ restoration of islet surface area and beta cell mass [39].

\section{What is the most appropriate way to estimate beta cell function in the context of exercise in patients with diabetes?}

Prior to examining the evidence for exercise preserving beta cell mass in humans, we first need to establish outcomes. Beta cell mass cannot be directly measured in humans. However, in most situations beta cell function can be accurately estimated through measurement of either insulin or, more appropriately, C-peptide, a component of the pre-insulin molecule [40]. At present, the most accurate approach for estimating beta cell function is through glucose clamping techniques. However, clamps are logistically and methodologically complex and are therefore impractical for large clinical trials. Instead, Cpeptide response to standard hyperglycaemic stimuli, calculated as 'area under the curve', is the recommended approach for monitoring therapy in clinical trials of beta cell preservation in type 1 diabetes [41].

Whilst stimulated C-peptide can accurately reflect beta cell function on a background of stable insulin sensitivity, it may underestimate beta cell function in the context of exercise. The increased insulin sensitivity that accompanies exercise will result in greater insulin action, to which the beta cell responds by reducing fasting as well as stimulated insulin production. The accuracy of beta cell function estimation in the context of exercise should therefore evaluate compensatory changes in insulin secretion in relation to the changes in insulin sensitivity. Models such as the disposition index, or techniques based on glucose and C-peptide measurements undertaken through a standard meal stimulated test have been demonstrated to reflect beta cell function in the context of insulin sensitivity $[42,43]$. A full validation of such models in type 1 diabetic patients or in exercise settings is yet to be undertaken, but they represent useful tools to explore the effects of exercise on beta cell function outside type 1 diabetes.

\section{What is the evidence for physical exercise preserving beta cell function in humans?}

Studies have now demonstrated that physical exercise preserves beta cell function in humans in health and at different stages of the natural history of type 2 diabetes (Table 1).

Beta cell preservation in healthy individuals In non-diabetic individuals, studies of meal-stimulated measures of insulin secretion have largely shown an adaptive reduction in GSIS following exercise (Table 1). However, studies that have used the disposition index have detected a preservation of beta cell function in relation to the training-induced increase in insulin sensitivity. The Studies of a Targeted Risk Reduction Intervention through Defined Exercise (STRRIDE) demonstrated that an 8 month walking exercise programme of $60 \mathrm{~min}$ on 3 days per week in 179 middle-aged overweight people reduced fasting insulin but improved beta cell function by $60 \%$ as measured by disposition index [44]. Interestingly subgroups that undertook more intensive exercise appeared to have a lower improvement in disposition index. The HEalth, RIsk factors, exercise Training And Genetics (HERITAGE) study [45], which was a 20 week cycle-based exercise programme involving 596 people, showed a $7 \%$ increase in insulin secretion during an intravenous glucose tolerance test (IVGTT) in the patient quartile with poorest baseline glucose tolerance. Thus, these large studies provided concordant results, strongly supporting a role for exercise in preserving beta cell function in subjects with normal glucose tolerance. Studies examining the effect of different types of exercise (i.e. strengthening vs aerobic) are lacking.

Beta cell preservation in patients with impaired glucose tolerance In subjects with abnormal glucose tolerance, a 1 week programme of exercise has been shown to produce a $27 \%$ improvement in the disposition index [46]. In addition, a study of 35 participants of a similar age with abnormal glucose tolerance reported an increase in insulin sensitivity and an improvement in the disposition index following 12 weeks of exercise [47].

Beta cell preservation in patients with type 2 diabetes Several groups have now documented beneficial effects of training on insulin secretory function in type 2 diabetic patients. The earliest reports date back to 1984 when Reitman and colleagues [48] showed in a small number of patients that the insulin response to an OGTT more than doubled following 2 months of intensive aerobic training. This increase in stimulated insulin response occurred whilst there was a fall in 


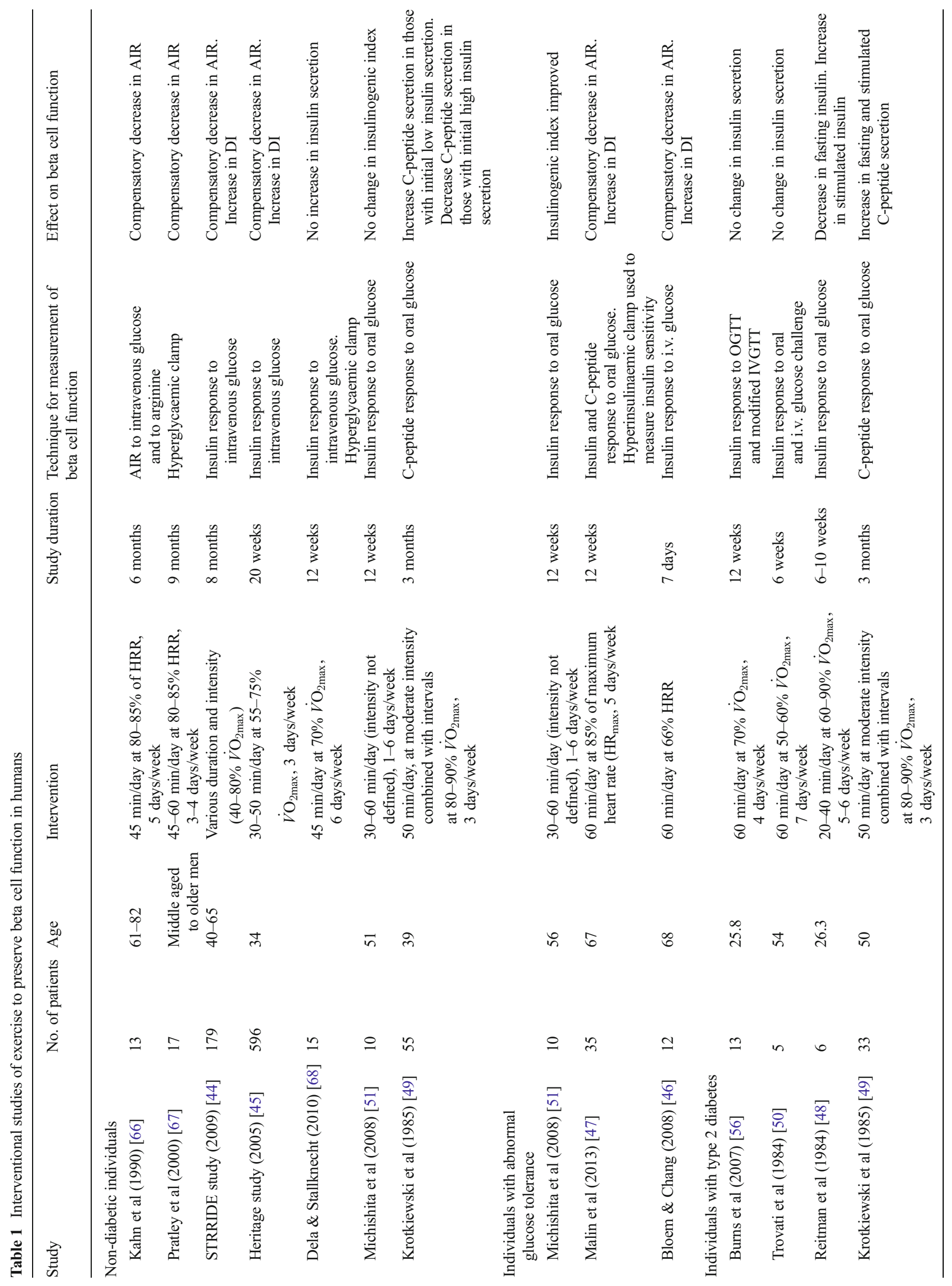




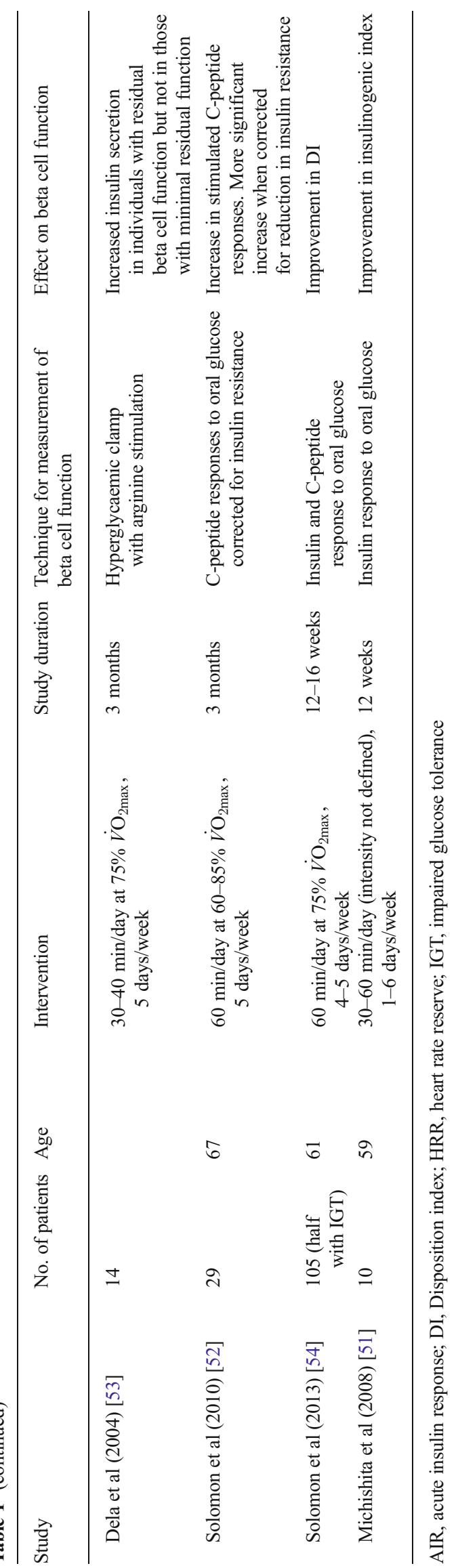


fasting insulin levels. This 'mixed' picture, again, is likely to reflect adaptive changes to beta cell function in the context of reducing insulin sensitivity. In 1985, Krotkiewski and colleagues showed that aerobic exercise training increased the C-peptide response to OGTT in type 2 diabetic patients [49], whereas other equally small studies reported that exercise does not significantly affect insulin secretion [50]. However, none of these studies accommodated for compensatory changes in insulin sensitivity.

There are a number of studies in type 2 diabetes that have attempted to accommodate for the changes in insulin action that accompany exercise. The insulinogenic index assesses insulin secretion in the context of insulin sensitivity and was used by Michishita et al to demonstrate increased insulin secretion during OGTT following aerobic training in type 2 diabetic patients [51]. Separately, we have also shown that oral glucose-induced insulin secretion (stimulated C-peptide) improves following 3 months of exercise training and dietinduced weight loss in type 2 diabetes [52]. Our study corrected the increase in insulin secretion for the improvement in insulin sensitivity, measured using a hyperinsulinaemiceuglycaemic clamp, and we observed a significant improvement in beta cell function. Dela et al demonstrated that C-peptide responses to intravenous glucose were increased as was arginine-mediated potentiation of glucose-stimulated insulin secretion following exercise training [53]. Assessment of insulin-mediated secretion in this study was assessed using a hyperglycaemic clamp, and differences in insulin secretion were detected only at glucose levels over $18 \mathrm{mmol} / \mathrm{l}$. Therefore, the strength of the stimulus to the beta cell can determine whether the intervention will have any detectable benefit. These subtleties are not considered with the current standard approach to testing beta cell function in type 1 diabetes studies.

Interestingly, studies in type 2 diabetes show that beta cell preservation appears to be greater in patients with significant pre-existing beta cell function $[49,54]$. This may explain why some studies $[55,56]$ have not found a beneficial effect of exercise on insulin secretory function in patients with type 2 diabetes. These findings further support the use of physical activity as a therapy for beta cell preservation in newly diagnosed patients with type 1 diabetes, where residual insulin secretory function is likely to be present.

Beta cell preservation in patients with type 1 diabetes The studies described above provide strong evidence that physical exercise, undertaken at levels that can be accommodated by the average type 2 diabetic patient, preserves beta cell function. However, the rate of beta cell loss is more aggressive in the presence of islet autoimmunity. Type 1 diabetic patients with detectable islet autoantibodies lose beta cell function faster than those who do not [57]. Similarly, the number and titre of islet autoantibodies predicts the rate of progression to diabetes in individuals at risk of type 1 diabetes [58]. Therefore exercise may not provide any clinically meaningful preservation of beta cell function in patients with new-onset type 1 diabetes, particularly those with elevated levels of islet autoantibodies. Whilst this can clearly only be tested with a properly designed randomised clinical trial, some support for this comes from studies of exercise in other autoimmune conditions. In Graves' thyroid disease, a structured exercise programme accelerated the withdrawal of anti-thyroid medication, and halved the relapse rate over the first year [59]. Like type 1 diabetes, psoriasis is a T cell-mediated disease. A small clinical trial of exercise and diet was recently shown to half severity of psoriasis disease activity [60]. Whilst not demonstrated in a clinical intervention trial, studies on multiple sclerosis have demonstrated that exercise associates with the preservation of grey and white matter and reduces the rate of relapse in animal models [61]. The benefits seen in these autoimmune diseases cannot be explained by improvements in insulin sensitivity, and suggest a direct effect on the autoimmune disease process.

\section{Discussion}

Preservation of beta cell function has important clinical benefits and is an important goal for people with type 1 diabetes. We have outlined mechanisms through which exercise could protect beta cell function, in addition to evidence in rodent models as well as humans with other types of diabetes, to support a role for exercise in the preservation of beta cell function. We have also outlined a disease-modifying effect in immune-mediated diseases outside type 1 diabetes. What are required now are clinical studies to test whether physical exercise can preserve beta cell function and, if so, the intensity, type (i.e. aerobic, resistance) and duration of exercise required for optimal benefit, and the effect of age, sex and antibody status on any benefit.

There is little disagreement that physical exercise has health benefits in type 1 diabetes, and that it should be encouraged as part of routine management. Exercise promotes fitness, reduces insulin requirement and lipids, improves endothelial function and well-being, and reduces insulin resistance, cardiovascular disease and mortality in patients with type 1 diabetes [62]. However, exercise is associated with an increased risk of hypoglycaemia and increased fluctuations of glucose levels that may explain why it does not always improve glycaemic control [63].

Meanwhile, studies have clearly shown that people with type 1 diabetes do not undertake sufficient exercise [64], and that exercise is not actively promoted or supported at the time of diagnosis with type 1 diabetes (unpublished work from our group, N. Lascar, S. Greenfield). The reasons for this are 
multi-factorial and complex, and include patient anxieties relating to hypoglycaemia and loss of control over their diabetes [65]. However, if exercise is shown to salvage residual beta cell function, there would be a strong argument to implement it much earlier in the natural history of this condition, and to develop strategies to encourage and support patients at this time. As a therapy, its attraction lies in the many health benefits it accrues, but also because it could be instituted alone, or as a combination therapy for beta cell preservation in type 1 diabetes.

Duality of interest The authors declare that there is no duality of interest associated with this manuscript.

Contribution statement All authors were responsible for the conception and design of the manuscript, drafting the article and revising it critically for important intellectual content. All authors approved the version to be published.

\section{References}

1. Atkinson MA, Eisenbarth GS (2001) Type 1 diabetes: new perspectives on disease pathogenesis and treatment. Lancet 358:221-229

2. Sherry NA, Tsai EB, Herold KC (2005) Natural history of beta-cell function in type 1 diabetes. Diabetes 54(Suppl 2):S32-S39

3. Oram RA, Jones AG, Besser REJ et al (2014) The majority of patients with long-duration type 1 diabetes are insulin microsecretors and have functioning beta cells. Diabetologia 57:187-191

4. Steffes MW, Sibley S, Jackson M, Thomas W (2003) Beta-cell function and the development of diabetes-related complications in the diabetes control and complications trial. Diabetes Care 26:832836

5. von Herrath M, Peakman M, Roep B (2013) Progress in immunebased therapies for type 1 diabetes. Clin Exp Immunol 172:186-202

6. Kroll JL, Beam C, Li S et al (2013) Reactivation of latent viruses in individuals receiving rituximab for new onset type 1 diabetes. J Clin Virol 57:115-119

7. Keymeulen B, Candon S, Fafi-Kremer S et al (2010) Transient Epstein-Barr virus reactivation in $\mathrm{CD} 3$ monoclonal antibody-treated patients. Blood 115:1145-1155

8. Ben Nasr M, D'Addio F, Usuelli V et al (2014) The rise, fall, and resurgence of immunotherapy in type 1 diabetes. Pharmacol Res. doi: 10.1016/j.phrs.2014.07.004

9. Nielsen JH, Linde S, Welinder BS et al (1989) Growth hormone is a growth factor for the differentiated pancreatic beta-cell. Mol Endocrinol 3:165-173

10. Jensen J, Galsgaard ED, Karlsen AE et al (2005) STAT5 activation by human GH protects insulin-producing cells against interleukin-1 $\beta$, interferon- $\gamma$ and tumour necrosis factor- $\alpha$-induced apoptosis independent of nitric oxide production. J Endocrinol 187:25-36

11. Choi SB, Jang JS, Hong SM et al (2006) Exercise and dexamethasone oppositely modulate beta-cell function and survival via independent pathways in $90 \%$ pancreatectomized rats. J Endocrinol 190: 471-482

12. Park S, Hong SM, Lee JE, Sung SR (2007) Exercise improves glucose homeostasis that has been impaired by a high-fat diet by potentiating pancreatic beta-cell function and mass through IRS2 in diabetic rats. J Appl Physiol 103:1764-1771
13. Ellingsgaard H, Hauselmann I, Schuler B et al (2011) Interleukin-6 enhances insulin secretion by increasing glucagon-like peptide-1 secretion from L cells and alpha cells. Nat Med 17:1481-1489

14. Ronsen O, Lea T, Bahr R, Pedersen BK (2002) Enhanced plasma IL6 and IL-1ra responses to repeated vs. single bouts of prolonged cycling in elite athletes. J Appl Physiol (1985) 92:2547-2553

15. Steensberg A, Fischer CP, Keller C et al (2003) IL-6 enhances plasma IL-1ra, IL-10, and cortisol in humans. Am J Physiol Endocrinol Metab 285:E433-E437

16. Moran A, Bundy B, Becker DJ et al (2013) Interleukin-1 antagonism in type 1 diabetes of recent onset: two multicentre, randomised, double-blind, placebo-controlled trials. Lancet 381:1905-1915

17. Cavelti-Weder C, Babians-Brunner A, Keller C et al (2012) Effects of gevokizumab on glycemia and inflammatory markers in type 2 diabetes. Diabetes Care 35:1654-1662

18. Ouchi N, Parker JL, Lugus JJ, Walsh K (2011) Adipokines in inflammation and metabolic disease. Nat Rev Immunol 11:85-97

19. Ben Ounis O, Elloumi M, Lac G et al (2009) Two-month effects of individualized exercise training with or without caloric restriction on plasma adipocytokine levels in obese female adolescents. Ann Endocrinol (Paris) 70:235-241

20. Pang TTL, Chimen M, Goble E et al (2013) Inhibition of islet immunoreactivity by adiponectin is attenuated in human type 1 diabetes. J Clin Endocrinol Metab 98:E418-E428

21. Oliveira M, Gleeson M (2010) The influence of prolonged cycling on monocyte Toll-like receptor 2 and 4 expression in healthy men. Eur J Appl Physiol 109:251-257

22. Gleeson M, McFarlin B, Flynn M (2006) Exercise and Toll-like receptors. Exerc Immunol Rev 12:34-53

23. Karstoft K, Winding K, Knudsen SH et al (2013) The effects of freeliving interval-walking training on glycemic control, body composition, and physical fitness in type 2 diabetic patients: a randomized, controlled trial. Diabetes Care 36:228-236

24. Solomon TPJ, Haus JM, Marchetti CM et al (2009) Effects of exercise training and diet on lipid kinetics during free fatty acid-induced insulin resistance in older obese humans with impaired glucose tolerance. Am J Physiol Endocrinol Metab 297:E552-E559

25. Donath MY, Gross DJ, Cerasi E, Kaiser N (1999) Hyperglycemiainduced beta-cell apoptosis in pancreatic islets of Psammomys obesus during development of diabetes. Diabetes 48:738-744

26. Garvey WT, Olefsky JM, Griffin J et al (1985) The effect of insulin treatment on insulin secretion and insulin action in type II diabetes mellitus. Diabetes 34:222-234

27. Hojberg PV, Zander M, Vilsboll T et al (2008) Near normalisation of blood glucose improves the potentiating effect of GLP-1 on glucoseinduced insulin secretion in patients with type 2 diabetes. Diabetologia 51:632-640

28. Paolisso G, Gambardella A, Amato L et al (1995) Opposite effects of short- and long-term fatty acid infusion on insulin secretion in healthy subjects. Diabetologia 38:1295-1299

29. Elks ML (1993) Chronic perifusion of rat islets with palmitate suppresses glucose-stimulated insulin release. Endocrinology 133: 208-214

30. Piro S, Anello M, Di Pietro C et al (2002) Chronic exposure to free fatty acids or high glucose induces apoptosis in rat pancreatic islets: possible role of oxidative stress. Metab Clin Exp 51:1340-1347

31. Strom A, Kolb H, Martin S et al (2012) Improved preservation of residual beta cell function by atorvastatin in patients with recent onset type 1 diabetes and high CRP levels (DIATOR trial). PLoS One 7: e33108

32. Coskun O, Ocakci A, Bayraktaroglu T, Kanter M (2004) Exercise training prevents and protects streptozotocin-induced oxidative stress and beta-cell damage in rat pancreas. Tohoku J Exp Med 203:145154 
33. Huang H-H, Farmer K, Windscheffel J et al (2011) Exercise increases insulin content and basal secretion in pancreatic islets in type 1 diabetic mice. Exp Diabetes Res 2011:481427

34. Shima K, Zhu M, Noma Y et al (1997) Exercise training in Otsuka Long-Evans Tokushima Fatty rat, a model of spontaneous noninsulin-dependent diabetes mellitus: effects on the B-cell mass, insulin content and fibrosis in the pancreas. Diabetes Res Clin Pract 35:11-19

35. Pold R, Jensen LS, Jessen N et al (2005) Long-term AICAR administration and exercise prevents diabetes in ZDF rats. Diabetes 54: 928-934

36. Király MA, Bates HE, Yue JTY et al (2007) Attenuation of type 2 diabetes mellitus in the male Zucker diabetic fatty rat: the effects of stress and non-volitional exercise. Metab Clin Exp 56:732-744

37. Király MA, Bates HE, Kaniuk NA et al (2008) Swim training prevents hyperglycemia in ZDF rats: mechanisms involved in the partial maintenance of beta-cell function. Am J Physiol Endocrinol Metab 294:E271-E283

38. Delghingaro-Augusto V, Decary S, Peyot M-L et al (2012) Voluntary running exercise prevents beta-cell failure in susceptible islets of the Zucker diabetic fatty rat. Am J Physiol Endocrinol Metab 302:E254 E264

39. Laker RC, Gallo LA, Wlodek ME et al (2011) Short-term exercise training early in life restores deficits in pancreatic beta-cell mass associated with growth restriction in adult male rats. Am J Physiol Endocrinol Metab 301:E931-E940

40. Kruszynska YT, Home PD, Hanning I, Alberti KG (1987) Basal and 24-h C-peptide and insulin secretion rate in normal man. Diabetologia 30:16-21

41. Palmer JP, Fleming GA, Greenbaum CJ et al (2004) C-peptide is the appropriate outcome measure for type 1 diabetes clinical trials to preserve beta-cell function: report of an $\mathrm{ADA}$ workshop, 21-22 October 2001. Diabetes 53:250-264

42. Retnakaran R, Qi Y, Goran MI, Hamilton JK (2009) Evaluation of proposed oral disposition index measures in relation to the actual disposition index. Diabet Med 26:1198-1203

43. Dalla Man C, Campioni M, Polonsky KS et al (2005) Two-hour seven-sample oral glucose tolerance test and meal protocol: minimal model assessment of beta-cell responsivity and insulin sensitivity in nondiabetic individuals. Diabetes 54:3265-3273

44. Slentz CA, Tanner CJ, Bateman LA et al (2009) Effects of exercise training intensity on pancreatic beta-cell function. Diabetes Care 32:1807-1811

45. Boule NG, Weisnagel SJ, Lakka TA et al (2005) Effects of exercise training on glucose homeostasis: the HERITAGE Family Study. Diabetes Care 28:108-114

46. Bloem CJ, Chang AM (2008) Short-term exercise improves beta-cell function and insulin resistance in older people with impaired glucose tolerance. J Clin Endocrinol Metab 93:387-392

47. Malin SK, Solomon TPJ, Blaszczak A et al (2013) Pancreatic betacell function increases in a linear dose-response manner following exercise training in adults with prediabetes. Am J Physiol Endocrinol Metab 305:E1248-E1254

48. Reitman JS, Vasquez B, Klimes I, Nagulesparan M (1984) Improvement of glucose homeostasis after exercise training in noninsulin-dependent diabetes. Diabetes Care 7:434-441

49. Krotkiewski M, Lonnroth P, Mandroukas K et al (1985) The effects of physical training on insulin secretion and effectiveness and on glucose metabolism in obesity and type 2 (non-insulin-dependent) diabetes mellitus. Diabetologia 28:881-890

50. Trovati M, Carta Q, Cavalot F et al (1984) Influence of physical training on blood glucose control, glucose tolerance, insulin secretion, and insulin action in non-insulin-dependent diabetic patients. Diabetes Care 7:416-420
51. Michishita R, Shono N, Kasahara T, Tsuruta T (2008) Effects of low intensity exercise therapy on early phase insulin secretion in overweight subjects with impaired glucose tolerance and type 2 diabetes mellitus. Diabetes Res Clin Pract 82:291-297

52. Solomon TPJ, Haus JM, Kelly KR et al (2010) Improved pancreatic beta-cell function in type 2 diabetic patients after lifestyle-induced weight loss is related to glucose-dependent insulinotropic polypeptide. Diabetes Care 33:1561-1566

53. Dela F, von Linstow ME, Mikines KJ, Galbo H (2004) Physical training may enhance beta-cell function in type 2 diabetes. Am J Physiol Endocrinol Metab 287:E1024-E1031

54. Solomon TPJ, Malin SK, Karstoft K et al (2013) Pancreatic beta-cell function is a stronger predictor of changes in glycemic control after an aerobic exercise intervention than insulin sensitivity. J Clin Endocrinol Metab 98:4176-4186

55. Kahleova H, Mari A, Nofrate V et al (2012) Improvement in beta-cell function after diet-induced weight loss is associated with decrease in pancreatic polypeptide in subjects with type 2 diabetes. J Diabetes Complications 26:442-449

56. Burns N, Finucane FM, Hatunic M et al (2007) Early-onset type 2 diabetes in obese white subjects is characterised by a marked defect in beta cell insulin secretion, severe insulin resistance and a lack of response to aerobic exercise training. Diabetologia 50:1500-1508

57. Dabelea D, Mayer-Davis EJ, Andrews JS et al (2012) Clinical evolution of beta cell function in youth with diabetes: the SEARCH for Diabetes in Youth study. Diabetologia 55:3359-3368

58. Maclaren N, Lan M, Coutant R et al (1999) Only multiple autoantibodies to islet cells (ICA), insulin, GAD65, IA-2 and IA-2beta predict immune-mediated (type 1) diabetes in relatives. J Autoimmun 12:279-287

59. Cutovic M, Konstantinovic L, Stankovic Z, Vesovic-Potic V (2012) Structured exercise program improves functional capacity and delays relapse in euthyroid patients with Graves' disease. Disabil Rehabil 34:1511-1518

60. Naldi L, Conti A, Cazzaniga S et al (2014) Diet and physical exercise in psoriasis: a randomized controlled trial. Br J Dermatol 170: 634-642

61. Dalgas U, Stenager E (2012) Exercise and disease progression in multiple sclerosis: can exercise slow down the progression of multiple sclerosis? Ther Adv Neurol Disord 5:81-95

62. Chimen M, Kennedy A, Nirantharakumar K et al (2012) What are the health benefits of physical activity in type 1 diabetes mellitus? A literature review. Diabetologia 55:542-551

63. Galassetti P, Riddell MC (2013) Exercise and type 1 diabetes (T1DM). Compr Physiol 3:1309-1336

64. Tielemans SMAJ, Soedamah-Muthu SS, de Neve M et al (2013) Association of physical activity with all-cause mortality and incident and prevalent cardiovascular disease among patients with type 1 diabetes: the EURODIAB Prospective Complications Study. Diabetologia 56:82-91

65. Brazeau A-S, Rabasa-Lhoret R, Strychar I, Mircescu H (2008) Barriers to physical activity among patients with type 1 diabetes. Diabetes Care 31:2108-2109

66. Kahn SE, Larson VG, Beard JC et al (1990) Effect of exercise on insulin action, glucose tolerance, and insulin secretion in aging. Am J Physiol 258:E937-E943

67. Pratley RE, Hagberg JM, Dengel DR et al (2000) Aerobic exercise training-induced reductions in abdominal fat and glucose-stimulated insulin responses in middle-aged and older men. J Am Geriatr Soc 48:1055-1061

68. Dela F, Stallknecht B (2010) Effect of physical training on insulin secretion and action in skeletal muscle and adipose tissue of firstdegree relatives of type 2 diabetic patients. Am J Physiol Endocrinol Metab 299:E80-E91 